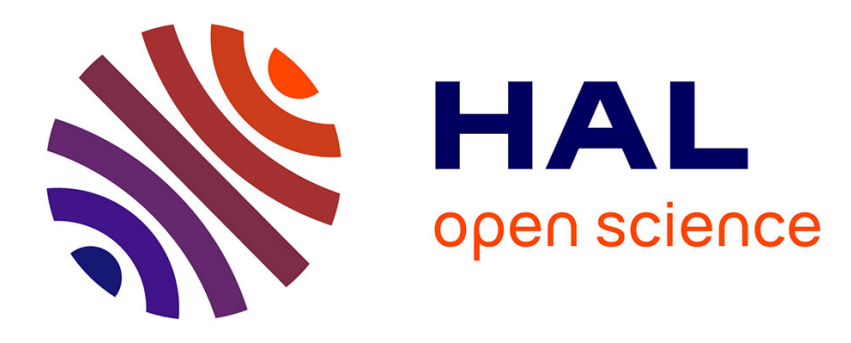

\title{
A new water-soluble polycarbobetaine showing high selectivity toward copper
}

Julia Mouton, Mireille Turmine, Hélène van den Berghe, Jean Coudane

\section{To cite this version:}

Julia Mouton, Mireille Turmine, Hélène van den Berghe, Jean Coudane. A new water-soluble polycarbobetaine showing high selectivity toward copper. Journal Chemical Engineering, 2016, 283, pp.11681175. 10.1016/j.cej.2015.08.058 . hal-01225359

\section{HAL Id: hal-01225359 https://hal.sorbonne-universite.fr/hal-01225359}

Submitted on 6 Nov 2015

HAL is a multi-disciplinary open access archive for the deposit and dissemination of scientific research documents, whether they are published or not. The documents may come from teaching and research institutions in France or abroad, or from public or private research centers.
L'archive ouverte pluridisciplinaire HAL, est destinée au dépôt et à la diffusion de documents scientifiques de niveau recherche, publiés ou non, émanant des établissements d'enseignement et de recherche français ou étrangers, des laboratoires publics ou privés. 


\section{A new water-soluble polycarbobetaine showing high selectivity toward}

\section{copper}

Julia Mouton*, Mireille Turmine, Hélène Van den Berghe, Jean Coudane

*Ass Prof. J. Mouton

EPF-Graduate school of engineering, 3 bis rue Lakanal, 92330 Sceaux, France

E-mail: julia.mouton@epf.fr

Ass Prof. M. Turmine

Sorbonne Universités, UPMC Univ Paris 06, UMR 8235, LISE, F-75005, Paris, France

CNRS, UMR 8235, LISE, F-75005, Paris, France

Ass Prof H. Van den Berghe

CNRS - UMR 5247 - Institut des Biomolécules Max Mousseron (IBMM), Université

Montpellier, Faculté de Pharmacie, 15, Avenue Charles Flahault, BP 14491, 34093

Montpellier cedex 05

Prof J. Coudane

CNRS - UMR 5247 - Institut des Biomolécules Max Mousseron (IBMM), Université Montpellier, Faculté de Pharmacie, 15, Avenue Charles Flahault, BP 14491, 34093 Montpellier cedex 05

In this study, betaine-type polyampholytes (polycarbobetaines, PCBets) are investigated as complexing agents of metal ions. Because PCBets are $\mathrm{pH}$-sensitive due to the presence of amine and carboxylic acid groups, the complexation of copper was monitored at various $\mathrm{pH}$ values (from 3 to 6) by UV-vis spectroscopy and/or electrochemical measurements. The results obtained for the complexation of copper were greatly enhanced as the $\mathrm{pH}$ increased and reached $264 \pm 11 \mathrm{mg} \mathrm{g}^{-1}$ at $\mathrm{pH}=6$. This maximum adsorption capacity rivals the recent results obtained for molecules of environmental interest, such as chitosan. The selectivity of the target PCBets for copper was indicated in the presence of nickel and/or cobalt and partially accounts for the interest in this material and demonstrated the relevance of using PCBet in environmental applications (such as metal recovery from wastes/wastewaters or environmental sensors). The efficiency of copper adsorption was maintained over 5 cycles of PCBet reuse $(91 \pm 4 \%)$.

Keywords: polycarbobetaines, copper, complexation, isotherms, selectivity, reusable 


\section{Introduction}

Currently, metals are highly studied in environmental management because of their depletion as resources and because of the increasingly common cases of pollution [1]. Thus, their recovery and valorization are key themes of recent scientific studies concerning the environment. Copper ions are produced as waste in various chemical industries, such as smelting, mining, printed circuit board manufacturing, electroplating, wire drawing, copper polishing, and paint manufacturing [2]. Various techniques, such as chemical precipitation, coagulation, solvent extraction, ultra-filtration, biological systems, electrolytic processes, reverse osmosis, oxidation with ozone/hydrogen peroxide, membrane filtration, ion exchange, photocatalytic degradation and adsorption, have been developed for the removal of metal contaminants from waste [3]. Among these techniques, precipitation appears as the most attractive, primarily because of its economical operation. However, one disadvantage exists when treating multi-element samples because all metals are typically precipitated together in sludge without any possibility to valorize them. Selective precipitating agents, such as dithiocarbamate and their ramifications, 2,4,6-trimercapto-1,3,5-triazine, or dipropyl dithiophosphate, have been studied, but their high cost inhibits their use for different industrial applications [4]. Adsorption is also a well-studied and efficient technique that has been considered more often for metal ion selective treatment [5]. Low-cost natural and synthetic adsorbents have already demonstrated good performances for copper removal from wastewaters [6-9]. Hydrogels are also considered for these applications [10]. However, these techniques are less cost-effective compared with precipitation when considering the clogging/unclogging operational problems in the technology.

This research is devoted to the study of polybetaines as metal ion precipitating agents. Polybetaines are specific polyampholytes that possess anionic and cationic groups on the same monomer unit. Among polybetaines, polysulfobetaines, polycarbobetaines and 
polyphosphobetaines are prominent [11]. This study investigates polycarbobetaines (PCBets) and their interactions with copper to design chemical processes for copper valorization. Cross-linked PCBet hydrogels have been tested for copper adsorption [2, 12, 13]; however, no literature exists about water-soluble PCBets for similar applications [14], although watersoluble polymers have been suggested to enhance filtration systems [15-17].

\section{Theorical background}

The interactions of water-soluble polymers with metal ions are treated as surface phenomena as previously reported [18]. The most appropriate method for assessing sorption capacity is the derivation of a whole sorption isotherm [19]. Over the years, a wide variety of equilibrium isotherm models (Langmuir, Freundlich, Brunauer-Emmett-Teller, Redlich-Peterson, Dubinin-Radushkevich, Temkin, Toth, Koble-Corrigan, Sips, Khan, Hill, Flory-Huggins and Radke-Prausnitz isotherm), have been formulated [20]. This study considers some two parameter isotherms only (Langmuir, Freundlich and Dubinin-Radushkevich). All of the equations and parameters used to model the adsorption isotherms are reported in Table 1 where Ce and Qe are respectively the concentration of free copper at the equilibrium $\left(\mathrm{mg} \mathrm{L}^{-1}\right)$, and the amount of copper adsorbed (mg) per gram of polymer.

The Langmuir equation is valid for monolayer sorption onto a surface with a finite number of identical sites [21]. It assumes a homogeneous surface and no interaction between the adsorbed species on adjacent active sites [22]. From equation presented in Table 1, one can readily deduce that at low sorbate concentrations it effectively reduces a linear isotherm. Alternatively, at high sorbate concentrations, it predicts a constant - monolayer - sorption capacity [23]. A separation factor or equilibrium parameter $\left(R_{L}\right)$ was defined from this model [24], as :

$$
\begin{gathered}
R_{L}=\frac{1}{1+K_{L} * C_{0}} \\
-3-
\end{gathered}
$$


where $\mathrm{C}_{0}$ is the highest initial concentration of adsorbate in solution $\left(\mathrm{mg} \mathrm{L}^{-1}\right)$.

Depending on its value, the isotherm shape can be interpreted as follows : $\mathrm{R}=0$ for the irreversible case, $0<\mathrm{R}<1$ for favorable equilibrium, $\mathrm{R}=1$ for the linear case, and $\mathrm{R}>1$ for unfavorable equilibrium [24].

The Freundlich equation is characteristic of multilayer adsorption, with non-uniform distribution of adsorption site and affinities over the heterogeneous surface. The magnitude of exponent $\mathrm{n}$ gives an indication on the favorability of adsorption. It is generally stated that the values $\mathrm{n}$ in the range of 2-10 represent good, 1-2 moderately difficult and less than 1 poor adsorption characteristics [25]. The Freundlich expression is an exponential equation and therefore, assumes that as the adsorbate concentration increases, the concentration of adsorbate on the adsorbent surface also increases. To determine the maximum adsorption capacity $(\mathrm{Qm})$, it is necessary to operate with constant initial concentration $C_{0}$ and variable weights of adsorbent; thus $\ln \mathrm{Qm}$ is the extrapolated value of $\ln q$ for $C=C_{0}$ as previously reported [26].

Dubinin-Radushkevich isotherm is generally applied to express the adsorption mechanism with a Gaussian energy distribution onto a heterogeneous surface. The model has often successfully fitted high solute activities and the intermediate range of concentrations data well. The approach was usually applied to distinguish the physical and chemical adsorption of metal ions [20]. The mean free energy (E) can be calculated as follows [27] :

$$
E=\left[\frac{1}{\sqrt{2 \times K_{D R}}}\right]
$$

The magnitude of free energy is used for estimating the type of adsorption mechanism. When ranging from 8 to $16 \mathrm{~kJ} \mathrm{~mol}^{-1}$, it indicates an ion-exchange process, beyond $16 \mathrm{~kJ} \mathrm{~mol}^{-1} \mathrm{a}$ coordination reaction is expected, and below $8 \mathrm{~kJ} \mathrm{~mol}^{-1}$ physisorption takes place [28]. One of the unique features of the Dubinin-Radushkevich isotherm model lies on the fact that it is temperature-dependent, which when adsorption data at different temperatures are plotted as a 
function of logarithm of amount adsorbed versus the square of potential energy, all suitable data will lie on the same curve, named as the characteristic curve [29, 30].

Thermodynamic data such as adsorption energy can be obtained from Langmuir equation and can be calculated by using the following equation [31]:

$$
K_{L}=e^{\frac{-\Delta G_{a d s}^{0}}{R \times T}}
$$

Table 1. Equations and parameters used to model the adsorption isotherms of copper on PCEGC

\begin{tabular}{lll}
\hline Name & Equation & Parameters \\
\hline Langmuir & $\mathrm{Qe}=\frac{\mathrm{Q}_{\mathrm{m}} * \mathrm{~K}_{\mathrm{L}} * \mathrm{C}_{\mathrm{e}}}{1+\mathrm{K}_{\mathrm{L}} * \mathrm{C}_{\mathrm{e}}}$ & $\mathrm{Qm}=$ Maximum adsorption capacity $\left(\mathrm{mg} \mathrm{g}^{-1}\right)$ \\
\hline Freunlich & $\mathrm{Qe}=\mathrm{K}_{\mathrm{f}} * \mathrm{C}_{\mathrm{e}}^{1 / \mathrm{n}}$ & $\mathrm{K}_{\mathrm{L}}=$ Isotherm constant $\left(\mathrm{L} \mathrm{mg}^{-1}\right)$ \\
\hline Dubinin- & $\mathrm{Qe}=\mathrm{Q}_{\mathrm{s}} * \exp \left[-\mathrm{Kdr} * \varepsilon^{2}\right]$ & $\mathrm{n}=$ adsotherm constant $\left(\mathrm{mg} \mathrm{g}^{-1}\left(\mathrm{~L} \mathrm{mg}^{-1}\right)^{1 / \mathrm{n}}\right)$ \\
Radushkevich & $\varepsilon=\mathrm{RT} * \ln \left(1+\frac{1}{\mathrm{C}_{\mathrm{e}}}\right)$ & $\mathrm{Q}=$ Maximum adsorption capacity $\left(\mathrm{mg} \mathrm{g}^{-1}\right)$ \\
\end{tabular}

\section{Materials and methods}

\section{1.} Materials

Acetoacetic ester (AAE, $\geq 99 \%$ ) and the initiator 2,2' azobisisobutyronitrile (AIBN, $\geq 98 \%$ ) were purchased from Aldrich and used without purification. Acrylic acid (AA, 99.5\%) purchased from Aldrich was purified by distillation under vacuum. Glycine (GLY, grade for analysis) was obtained from Merck. Ammonia solution $\left(\mathrm{NH}_{4} \mathrm{OH} 30 \%\right.$, ACS) and sulfuric acid $\left(\mathrm{H}_{2} \mathrm{SO}_{4} 96 \%\right.$, for analysis) were obtained from Carlo-Erba. Analytical reagent grade, sodium 
hydroxide $(\mathrm{NaOH})$, anhydrous sodium sulfate $\left(\mathrm{Na}_{2} \mathrm{SO}_{4}\right)$, copper sulfate $\left(\mathrm{CuSO}_{4} \cdot 5 \mathrm{H}_{2} \mathrm{O}\right)$, nickel sulfate hexahydrate $\left(\mathrm{NiSO}_{4} \cdot 6 \mathrm{H}_{2} \mathrm{O}\right)$ and the reagent grade solvent acetone were purchased from VWR. Cobalt sulfate (extra pure, $\mathrm{CoSO}_{4} \cdot 7 \mathrm{H}_{2} \mathrm{O}$ ) was obtained from Acros Organics.

\subsection{Analytical techniques}

FTIR spectra were recorded using a Perkin-Elmer Spectrum 100 FTIR spectrometer using the attenuated-total-reflectance (ATR) method. ${ }^{1} \mathrm{H}-\mathrm{NMR}$ spectra were recorded using a Bruker spectrometer (AMX300) operating at $300 \mathrm{MHz}$. Deuterium oxide $\left(\mathrm{D}_{2} \mathrm{O}\right)$ was used as the solvent. The chemical shifts are expressed in ppm with respect to tetramethylsilane (TMS). The UV-vis spectra of the polymer solutions were recorded on a Hitachi U4001 spectrophotometer with a scan range of 220-900 nm. Free copper in the solutions was followed on a PHM250 ion analyzer equipped with a copper selective electrode (CSE) (Radiometer-ISE25Cu) and a sulfate reference electrode (Radiometer REF621). Figure 1 and Table 2 present the characteristics of the electrochemical method. The $\mathrm{pH}$ was also recorded using a PHM250 ion analyzer equipped with a glass electrode (Radiometer pHG301) and the same sulfate reference electrode. 


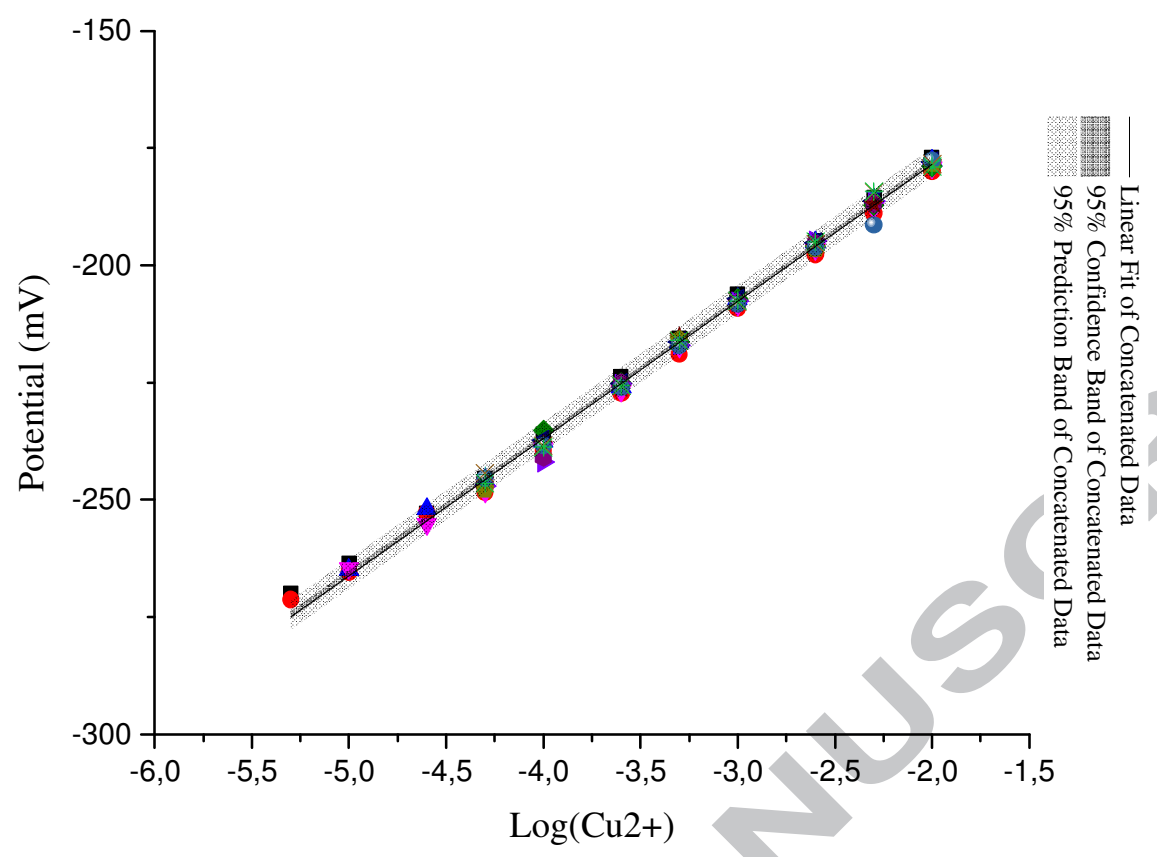

Figure 1. Calibration mean of the copper selective electrode in $\mathrm{Na}_{2} \mathrm{SO}_{4} 0.1 \mathrm{~mol} \mathrm{~L}^{-1}$ at $\mathrm{pH}$ $=5$ (based on fourteen replicates).

Table 2. Parameters of the electrochemical analytical method in $\mathrm{Na}_{2} \mathrm{SO}_{4} 0.1$ mol L ${ }^{-1}$ at $\mathrm{pH}=5$ (based on fourteen replicates)

\begin{tabular}{lll}
\hline Parameters & Mean & Standard deviation \\
\hline Slope & 29.3 & 0.2 \\
Intercept & -119.9 & 0.6 \\
Determination coefficient $\left(\mathrm{R}^{2}\right)$ & 0.9966 & - \\
Number of points & 115 & - \\
Concentration range $\left(\mathrm{mol} \mathrm{L}^{-1}\right)$ & $5 \times 10^{-6}-1 \times 10^{-2}$ & - \\
Detection limit* $\left(\mathrm{mg} \mathrm{L}^{-1}\right)$ & 0.8 & - \\
\hline
\end{tabular}

$*[32]$ 


\subsection{Syntheses}

The monomer was obtained by dropwise addition of a glycine $16 \%$ aqueous solution $(37 \mathrm{~mL})$ to acetoacetic ester $(10 \mathrm{~mL})$ under magnetic stirring for 3 hours. The solution was then left overnight to decant (12 hours), and the organic phase containing the key product ethyl-3glycinatocrotonate (EGC) was collected. The yield of the monomer was $98 \%$, and its purity was tested by FTIR. The linear water-soluble polycarbobetaine named polycarboxyethyl-3glycinatocrotonate (PCEGC) was synthesized by radical polymerization, as previously reported [13, 33], by mixing EGC, AA and the initiator AIBN (5 minutes). The polymer obtained in bulk was washed with an abundant amount of acetone and oven-dried at $70^{\circ} \mathrm{C}$ (approximately 35\% yield). 
<smiles>CCOC(=O)CC(C)=O</smiles><smiles>NCC(=O)O</smiles><smiles>CCOC(=O)CC(C)=NCC(=O)O</smiles><smiles>O=CNCC(=O)O</smiles><smiles>C=C(C=C(C)C)OCC</smiles><smiles>C=CC(=O)O</smiles>

[<smiles>CCOC(=O)C=C(C)N(CC(=O)O)CC(=O)O</smiles>
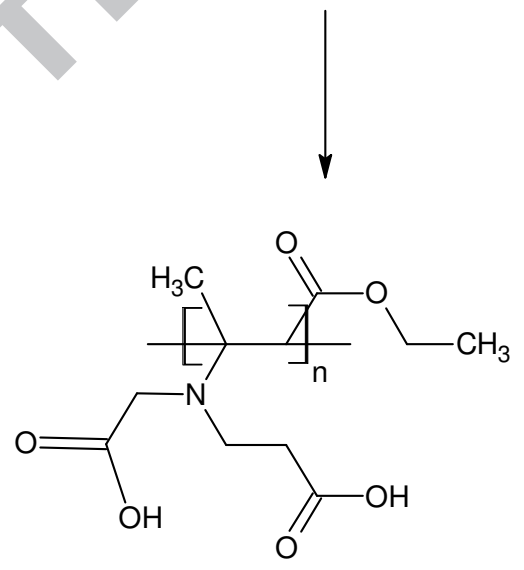

Scheme 1. Monomer and polymer syntheses. 


\subsection{Sorption experiments}

The sorption experiments were performed by the batch method $(10 \mathrm{~mL})$ in a thermostated cell $\left(25^{\circ} \mathrm{C}\right)$ with constant stirring, using PCEGC $0.5 \mathrm{~g} \mathrm{~L}^{-1}$. The adsorption behavior of the copper ions $(\mathrm{Cu}(\mathrm{II}))$ was assayed over a range from $5.10^{-5}$ to $510^{-3} \mathrm{~mol} \mathrm{~L}^{-1}$ and over a $\mathrm{pH}$ range from 3 to 6 . The ionic strength (I) was fixed at $0.3 \mathrm{~mol} \mathrm{~L}^{-1}$ with $\mathrm{Na}_{2} \mathrm{SO}_{4} 0.1 \mathrm{~mol} \mathrm{~L}^{-1}$. The $\mathrm{pH}$ was adjusted with $\mathrm{H}_{2} \mathrm{SO}_{4}$ or $\mathrm{NaOH}$. Adsorption isotherms were determined by monitoring free copper decay in the solution and were fitted to the Langmuir, Freundlich and DubininRadushkevich models. The amount of copper adsorbed in $(\mathrm{mg} / \mathrm{g})$ at equilibrium $(\mathrm{Qe})$, defined as the soluble and precipitated fractions of PCEGC/Cu complex, was calculated from the mass balance of initial and final copper concentrations:

$$
Q_{e}=\frac{\left(C_{0}-C_{e}\right) \times V_{T o t}}{W_{P C E G C}}
$$

where $\mathrm{C}_{0}$ and $\mathrm{Ce}$ are respectively the initial concentration of copper and the concentration at the equilibrium, $\mathrm{V}_{\text {Tot }}$ is the total volume of the solution $(\mathrm{L})$ and $\mathrm{W}_{\text {PCEGC }}$ is the weight of the $\operatorname{PCEGC~(g).~}$

Some of the assays were used to test the selectivity of PCEGC toward copper, cobalt $\left(\mathrm{Co}^{2+}\right)$ and nickel $\left(\mathrm{Ni}^{2+}\right)$ using electrochemical measurements and UV-visible spectroscopy.

All of the experiments were conducted in triplicate under identical conditions.

The adsorption isotherms were determined by using non-linear regression analysis. The error function employed to evaluate the fit was the second order corrected Akaike information criterion (AICC) defined as follows [25, 28]:

$$
\begin{gathered}
A I C=N \times \operatorname{Ln}\left(\frac{R S S}{N}\right)+2 P \\
A I C_{C}=A I C+\frac{2 P \times(P+1)}{N-P-1}
\end{gathered}
$$

where $\mathrm{P}$ is the number of parameters in the model $(\mathrm{P}=2), \mathrm{N}$ the number of data points and RSS the residual squares sum. 
AICc considers the size of the calibration data set and is therefore preferred over the original AIC [34].

\subsection{Sorption/desorption cycles experiments}

Sorption/desorption experiments were performed over 5 cycles by $\mathrm{pH}$ adjustments. A solution of copper $0.005 \mathrm{~mol} \mathrm{~L}^{-1}$ and PCEGC $0.5 \mathrm{~g} \mathrm{~L}^{-1}$ was prepared in $\mathrm{Na}_{2} \mathrm{SO}_{4} 0.1 \mathrm{~mol} \mathrm{~L}^{-1}$ at $\mathrm{pH}=5$ (the final $\mathrm{pH}$ was 4.5). Desorption experiments were performed by decreasing the $\mathrm{pH}$ to 2 , and the next adsorption cycle was obtained by $\mathrm{pH}$ adjustment back to 4.5 . The $\mathrm{pH}$ was adjusted with $\mathrm{H}_{2} \mathrm{SO}_{4}$ or $\mathrm{NaOH}$. This operation was conducted four more times. The free copper in solution was followed by CSE and the concentration was corrected considering the volume increase due to $\mathrm{H}_{2} \mathrm{SO}_{4}$ or $\mathrm{NaOH}$ addition. The adsorption-desorption behavior of the $\mathrm{Cu}$ (II) was assayed in the absence and in the presence of cobalt or nickel ions.

All of the experiments were conducted in triplicate under identical conditions.

\section{Results and Discussion}

\subsection{Characterization}

$\mathrm{CH}_{2}$ and $\mathrm{CH}_{3}$ groups of the ethyl function were clearly identified by the presence of a quadruplet at $3.97 \mathrm{ppm}$ and a triplet at $1.03 \mathrm{ppm}$, respectively, in ${ }^{1} \mathrm{H}$ NMR spectra of pure PCEGC. The other hydrogen atoms were observed over the expected range (from 1.43 to 2.54 ppm). No comparison could be performed with the ${ }^{1} \mathrm{H}$ NMR spectra of PCEGC/Cu complexes due to their insolubility in $\mathrm{D}_{2} \mathrm{O}$.

The main functional groups were identified by FTIR spectroscopy for PCEGC, including the $\mathrm{O}-\mathrm{H}$ stretching vibration at $3124 \mathrm{~cm}^{-1}$; $\mathrm{C}-\mathrm{H}$ stretching vibration at $2956 \mathrm{~cm}^{-1}$; and $\mathrm{C}=\mathrm{O}$ stretching vibration at $1701 \mathrm{~cm}^{-1}$, as previously reported for a similar structure (polycarboxyethyl-3-aminocrotonate) [35, 36]. The results are presented in Figure 1a and 
remained unchanged in the $\mathrm{PCEGC} / \mathrm{Cu}$ complex. No carboxylate asymmetric stretching vibrations were recorded, while a symmetric vibration appeared at $1415 \mathrm{~cm}^{-1}$. This tendency changes in the case of the PCEGC/Cu complex, with the appearance of a medium asymmetric stretching vibration at $1608 \mathrm{~cm}^{-1}$, which is characteristic of copper carboxylates [37]. The difference between these two well-known characteristic bands in the PCEGC/Cu complex $\left(193 \mathrm{~cm}^{-1}\right)$ indicated that the coordination of the carboxylate groups occurred in a bridged form [38].

The aqueous solution of PCEGC $0.5 \mathrm{~g} \mathrm{~L}^{-1}\left(\mathrm{I}=0.3 \mathrm{~mol} \mathrm{~L}^{-1}\right.$ at $\left.\mathrm{pH}=5\right)$ exhibits an absorbance peak approximately $280 \mathrm{~nm}$, which is specific to carboxylic groups (Figure 1b), while the copper solution absorbs at $816 \mathrm{~nm}$. Figure $1 \mathrm{~b}$ shows that the maximum absorption for the PCEGC/Cu complex shifted from $816 \mathrm{~nm}$ to $702 \mathrm{~nm}$ and indicated the coordination interactions between the species. This band is characteristic of square-pyramidal copper(II) complexes [37]. In addition, the specific peak of PCEGC at $280 \mathrm{~nm}$ was markedly increased in the presence of copper (from 0.04 to 0.87 ), confirming the interaction between copper and polycarbobetaine carboxylate groups. This band is assigned to the carboxylate-to-copper charge transfer (ligand-to-metal charge transfer) [38]. 

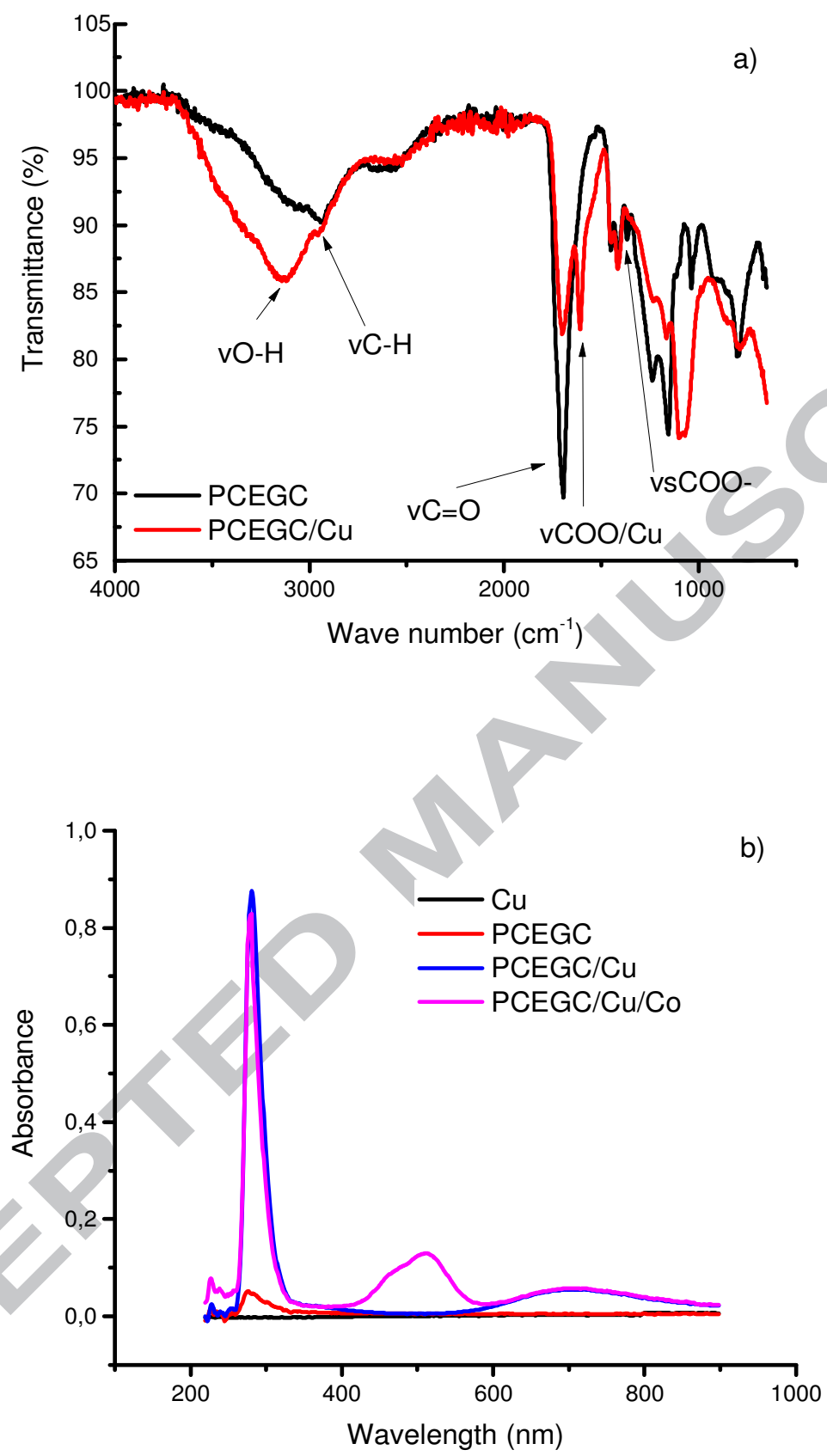

Figure 2. IR spectra of PCEGC and PCEGC/Cu complexes (a), and UV-visible spectra of PCEGC (0.5 $\left.\mathrm{g} \mathrm{L}^{-1}\right), \mathrm{Cu}(\mathrm{II})\left(0.0005 \mathrm{~mol} \mathrm{~L}^{-1}\right)$ and/or Co(II) $\left(0.025 \mathrm{~mol} \mathrm{~L}^{-1}\right)$ in $0.1 \mathrm{~mol} \mathrm{~L}^{-1}$ $\mathrm{Na}_{2} \mathrm{SO}_{4}$ at $\mathrm{pH}=5(\mathrm{~b})$. 


\subsection{Copper complexation}

The mechanisms of copper uptake by PCEGC at pH 3.0, 4.0, 5.0, and 6.0 were explored by analyzing the results of the adsorption isotherms (the experimental and predicted isotherms are presented in figure 3). All the parameters extracted from the fitting models are gathered in Table 3 for $\mathrm{pH} 4$ to 6 .

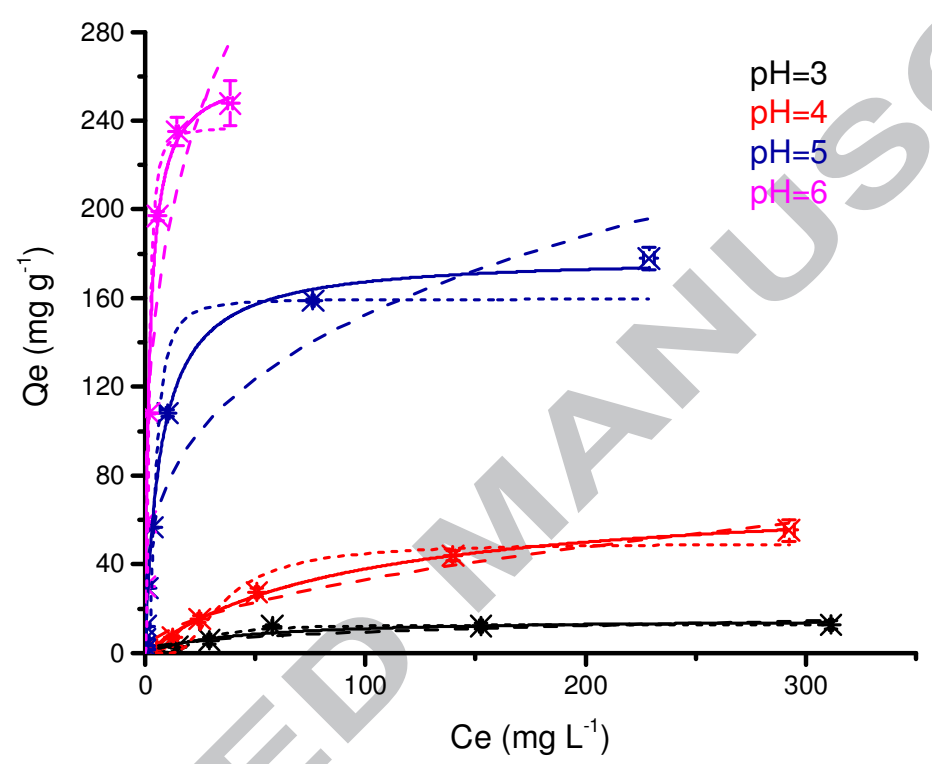

Figure 3. Adsorption isotherms of copper onto PCEGC at various $\mathrm{pH}$ values. Experimental data fitted to the Langmuir model (solid line), the Freundlich model (dashed line) and the Dubinin-Raduskevich model (dotted line).

The adsorption capacities at equilibrium (Qe) were low at $\mathrm{pH} 3.0$ (around the detection limits); thus, this $\mathrm{pH}$ condition did not explain the binding mechanisms. As shown in Table 3, the difference between the corrected Akaike information criterion of the Freundlich or Dubinin-Radushkevich models and the Langmuir model was greater than nine, providing strong evidence favoring the Langmuir model as the best to describe the interaction between copper and PCEGC [39]. The best fit to the Langmuir model translates the predominantly 
homogeneous distribution of the chelating groups on the polymer chains because the Langmuir equation assumes that the adsorbent surface is energetically homogeneous.

Table 3. Isotherm model parameters for $\mathrm{Cu}(\mathrm{II})$ adsorption on PCEGC at different $\mathrm{pH}$ values.

\begin{tabular}{|c|c|c|c|c|}
\hline Models & Parameters & $\mathrm{pH}=4$ & $\mathrm{pH}=5$ & $\mathrm{pH}=6$ \\
\hline \multirow[t]{6}{*}{ Langmuir } & $\mathrm{Qm}\left(\mathrm{mg} \mathrm{g}^{-1}\right)$ & $73.3 \pm 3.4$ & $179 \pm 3$ & $264 \pm 11$ \\
\hline & $\mathrm{b}\left(\mathrm{L} \mathrm{mg}^{-1}\right)$ & $0.011 \pm 0.001$ & $0.14 \pm 0.01$ & $0.49 \pm 0.08$ \\
\hline & $\mathrm{R}^{2}$ & 0.9960 & 0.9972 & 0.9881 \\
\hline & $\Delta_{\mathrm{r}} \mathrm{G}\left(\mathrm{kJ} \mathrm{mol}^{-1}\right)$ & $-16.0 \pm 3.4$ & $-22.6 \pm 1.7$ & $-25.6 \pm 4.4$ \\
\hline & $\mathrm{R}_{\mathrm{L}}$ & 0.228 & 0.021 & 0.031 \\
\hline & $\mathrm{AIC}_{\mathrm{C}}{ }^{\mathrm{a})}$ & 10.4 & 28.3 & 34.7 \\
\hline \multirow[t]{5}{*}{ Freundlich } & $\mathrm{K}_{\mathrm{f}}\left(\mathrm{mg} \mathrm{g}^{-1}\left(\mathrm{~L} \mathrm{mg}^{-1}\right)^{1 / n}\right)$ & $2.87 \pm 1.08$ & $37.6 \pm 7.8$ & $96.8 \pm 16.7$ \\
\hline & $\mathrm{n}$ & $1.88 \pm 0.26$ & $3.29 \pm 0.48$ & $3.49 \pm 0.72$ \\
\hline & $\mathrm{R}^{2}$ & 0.9607 & 0.9322 & 0.9065 \\
\hline & $\mathrm{AIC}_{\mathrm{C}}^{\mathrm{a})}$ & 24.1 & 57.1 & 47.1 \\
\hline & $\Delta \mathrm{AIC}_{\mathrm{C}}^{\mathrm{b})}$ & 13.7 & 28.8 & 12.4 \\
\hline \multirow{6}{*}{$\begin{array}{l}\text { Dubinin- } \\
\text { Radushkevich }\end{array}$} & $\mathrm{Q}_{\mathrm{S}}\left(\mathrm{mg} \mathrm{g}^{-1}\right)$ & $49.5 \pm 4.7$ & $160 \pm 11$ & $237 \pm 22$ \\
\hline & $\mathrm{B}_{\mathrm{D}}\left(\mathrm{mol}^{2} \mathrm{~kJ}^{-2}\right)$ & $\begin{array}{l}1.64 \times 10^{-} \\
\pm 5.78 \times 10^{-5}\end{array}$ & $\begin{array}{l}3.29 \times 10^{-6} \\
\pm 9.95 \times 10^{-7}\end{array}$ & $\begin{array}{l}6.53 \times 10^{-7} \\
+2.79 \times 10-^{7}\end{array}$ \\
\hline & $\mathrm{E}\left(\mathrm{kJ} \mathrm{mol}^{-1}\right)$ & $55.3 \pm 9.7$ & $390 \pm 59$ & $875 \pm 187$ \\
\hline & $\mathrm{R}^{2}$ & 0.9241 & 0.9446 & 0.8916 \\
\hline & $\mathrm{AIC}_{\mathrm{C}}^{\mathrm{a})}$ & 28.02 & 55.27 & 47.98 \\
\hline & $\Delta \mathrm{AIC}_{\mathrm{C}}{ }^{\mathrm{b})}$ & 17.6 & 26.9 & 13.2 \\
\hline
\end{tabular}

a) Corrected Akaike information criterion [39]; b) Difference between one model $\mathrm{AIC}_{\mathrm{C}}$ and Langmuir $\mathrm{AIC}_{\mathrm{C}}$

Considering the separation factor $\left(\mathrm{R}_{\mathrm{L}}\right)$, adsorption can be considered unfavorable $\left(\mathrm{R}_{\mathrm{L}}>1\right)$, linear $\left(\mathrm{R}_{\mathrm{L}}=1\right)$, favorable $\left(1>\mathrm{R}_{\mathrm{L}}>0\right)$ or irreversible $\left(\mathrm{R}_{\mathrm{L}}=0\right)$ [40]. $\mathrm{R}_{\mathrm{L}}$ calculated with the Langmuir model indicated the favorable adsorption of $\mathrm{Cu}$ (II) onto PCEGC (ranging from 0.2 to 0.02 , depending on $\mathrm{pH})$. This observation was confirmed by the values of $n(>1)$ from the Freundlich model [41]. The values of free energy change $\left(\Delta_{\mathrm{r}} \mathrm{G}<0\right)$ corroborated the spontaneity of the reaction. The maximum adsorption capacity (Qm) was substantially increased (from 15.5 to $264 \mathrm{mg} \mathrm{g}^{-1}$ ) as the $\mathrm{pH}$ increased (from 3 to 6) and appeared linearly correlated to this parameter (Figure 3). 

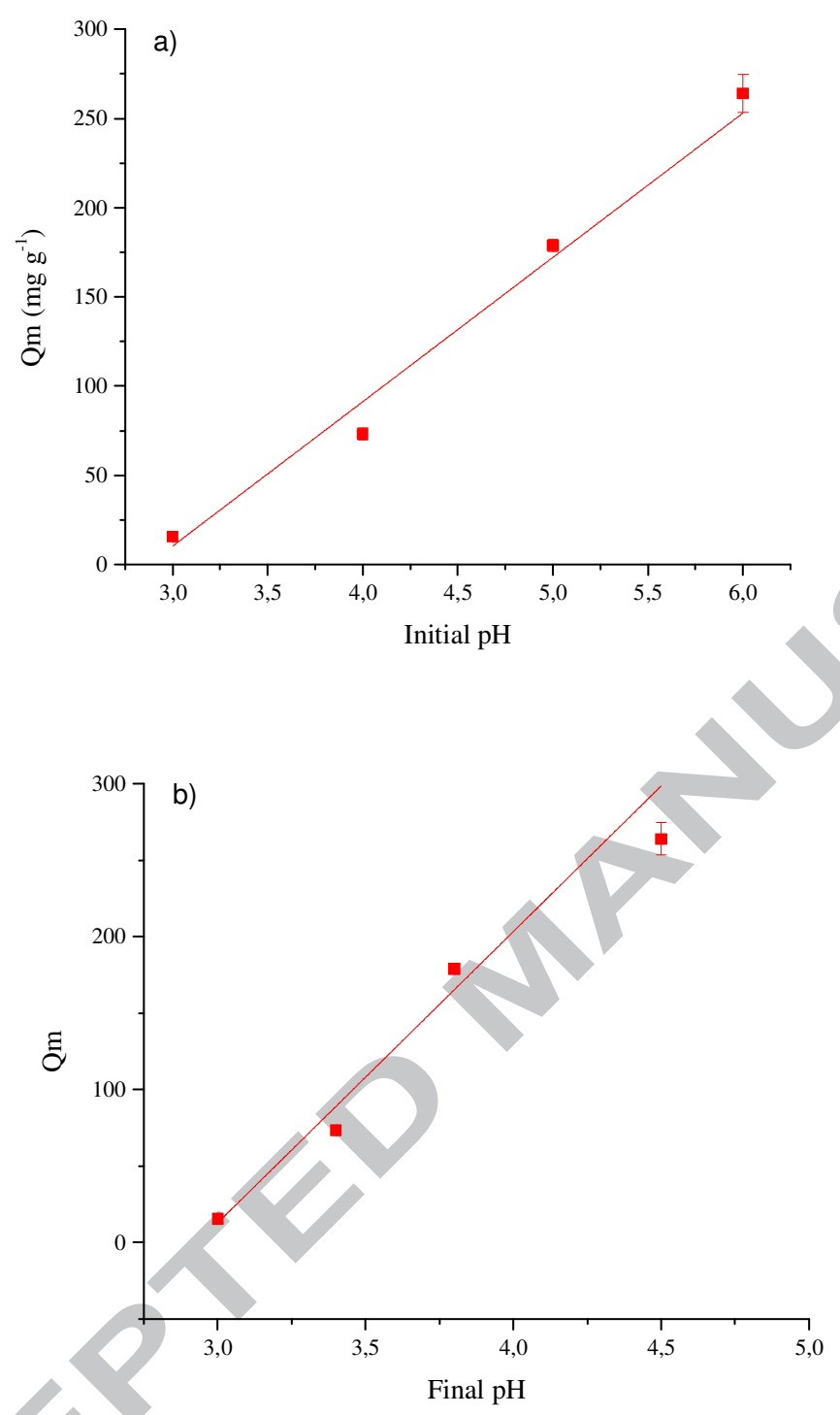

Figure 4. Maximum adsorption capacity of PCEGC correlated to a) initial $\mathrm{pH}\left(\mathrm{R}^{2}=0.98012\right)$; b) final $\mathrm{pH}\left(\mathrm{R}^{2}=0.97312\right)$.

The mean free energy of sorption (E) derived from the Dubinin-Radushkevich equation provides information on the type of sorption reaction [23]. An energy range from 8 to $16 \mathrm{~kJ}$ $\mathrm{mol}^{-1}$ indicates an ion-exchange process, and a value above $16 \mathrm{~kJ} \mathrm{~mol}^{-1}$ indicates a coordination reaction [28]. The results presented in Table 1 suggest that coordinative 
interactions occurred between PCBets and $\mathrm{Cu}$ and confirm the chemisorption of copper onto PCEGC. This conclusion can help to explain previous observations in which Qm increased as the $\mathrm{pH}$ increased. The functional groups most likely involved in the complexation reaction are carboxylic groups $(\mathrm{COOH})$. Thus, a higher $\mathrm{pH}$ indicates that a larger amount of $\mathrm{COOH}$ groups is deprotonated to $\mathrm{COO}^{-}$, thus making them available to complex copper by dative bonds.

Table 4 shows the maximum adsorption capacities of various natural and synthetic materials recently studied for copper recovery from waste or wastewater. PCEGC clearly appears as a promising agent for these applications, especially considering its potential regeneration for future use (as observed for similar PCBets in previous studies) [13]. 
Table 4. Previously reported adsorption capacities of $\mathrm{Cu}$ (II) onto various adsorbents.

\begin{tabular}{|c|c|c|c|c|c|}
\hline Origins & Adsorbents & Qm $\quad\left(\mathrm{mg} \mathrm{g}^{-1}\right)$ & $\mathbf{p H}$ & $\mathbf{T}^{\circ}\left({ }^{\circ} \mathbf{C}\right)$ & References \\
\hline \multirow[t]{10}{*}{ Natural } & Shell of lentil & 8.98 & 6 & 20 & {$[6]$} \\
\hline & Shell of wheat & 7.39 & 6 & 20 & \\
\hline & Shell of rice & 1.85 & 6 & 20 & \\
\hline & Banana pith & 13.5 & 4.5 & - & {$[42]$} \\
\hline & Peath & 12.7 & 4.5 & 25 & {$[23]$} \\
\hline & Oyster shell & 49.3 & 2 & 30 & [7] \\
\hline & \multirow[t]{2}{*}{ Calcium alginate beads } & 84.5 & 4.5 & 25 & {$[43]$} \\
\hline & & 12.1 & 4.8 & 22 & {$[44]$} \\
\hline & Lignin & 22.9 & 5.5 & 20 & {$[45]$} \\
\hline & Chitosan & 208 & 6 & 25 & {$[8]$} \\
\hline \multirow[t]{6}{*}{ Synthetic } & Nanohydroxyapatite & 4.4 & 5.5 & 25 & {$[5]$} \\
\hline & Polyacrylic acid $3 \times 10^{6} \mathrm{~g} \mathrm{~mol}^{-1}$ & 369 & 6 & 25 & {$[46]$} \\
\hline & Polyethylene imine & 333 & & 25 & [47] \\
\hline & ASA-PGMA/SiO ${ }_{2}{ }^{\mathrm{a}}$ & 37 & & 20 & {$[48]$} \\
\hline & Amino functionalized silica gel & 54 & 5 & 30 & [49] \\
\hline & PCEGC & 264 & 6 & 25 & This study \\
\hline
\end{tabular}

${ }^{\text {a }}$ 5-aminosalicylic acid (ASA) grafted onto the poly(glycidyl methacrylate) (PGMA) 


\subsection{Copper selectivity}

The influence of nickel $\left(\mathrm{Ni}^{2+}\right)$ and cobalt $\left(\mathrm{Co}^{2+}\right)$ on copper adsorption was investigated by electrochemical measurements (Figure 2). Copper solutions at $5.10^{-4} \mathrm{~mol} \mathrm{~L}^{-1}\left(-215.6<\mathrm{E}_{\mathrm{Cu}}<-\right.$ $216.3 \mathrm{mV}$ ) were prepared in $0.1 \mathrm{~mol} \mathrm{~L}^{-1} \mathrm{Na}_{2} \mathrm{SO}_{4}$ at $\mathrm{pH}=5$ with several different concentrations of metallic ions $\left(\mathrm{Ni}^{2+}\right.$ or $\left.\mathrm{Co}^{2+}\right)$. The ratio $(\mathrm{R}=$ concentration of metallic ion/concentration of copper) was fixed to $0,0.5,1,2,5$ and 10 (the linearity of the electrode response was lost for higher ratios). Under these conditions, regardless of the metal and the ratio used, the potential of the electrode remained unchanged (with values between -215.6 and $-216.3 \mathrm{mV})$.

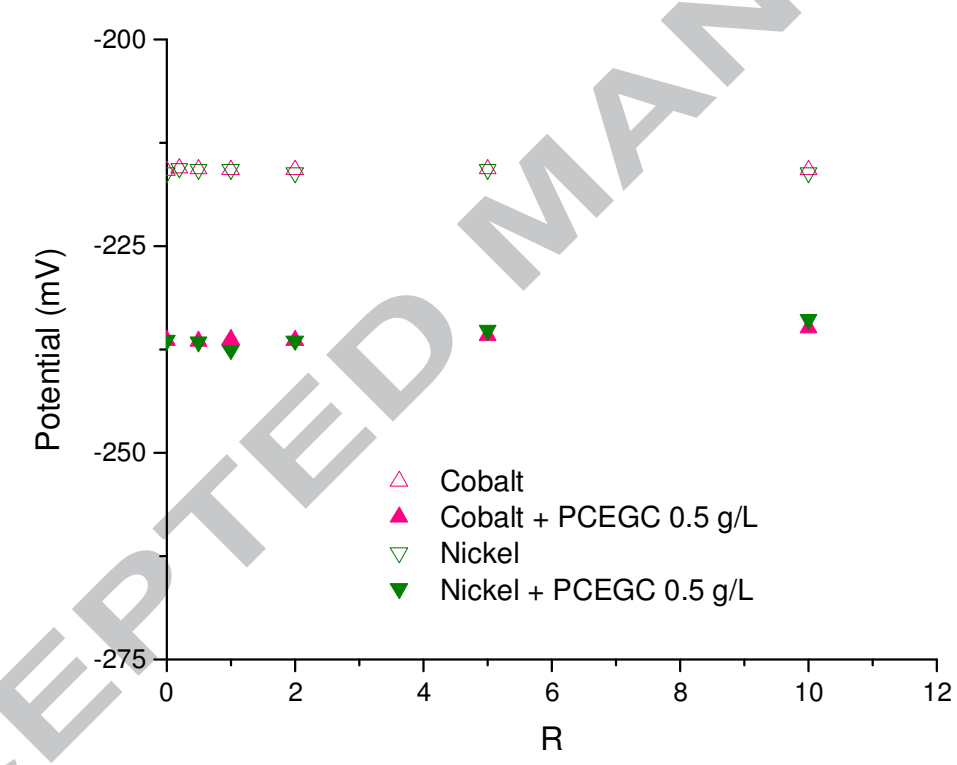

Figure 5. Selectivity of PCEGC toward $\mathrm{Cu}(\mathrm{II})\left(510^{-4} \mathrm{~mol} \mathrm{~L}^{-1}\right)$ in the presence of $\mathrm{Co}^{2+}$ or $\mathrm{Ni}^{2+}$ at varying concentrations in $0.1 \mathrm{~mol} \mathrm{~L}^{-1} \mathrm{Na}_{2} \mathrm{SO}_{4}$ at $\mathrm{pH}=5(\mathrm{R}=[$ metallic ion $] /[\mathrm{Cu}(\mathrm{II})])$.

The potential was kept constant (ranging from -235.20 to $-236.50 \mathrm{mV}$ ) with the addition of PCEGC $\left(0.5 \mathrm{~g} \mathrm{~L}^{-1}\right)$ to the same solutions, suggesting that $\mathrm{Co}^{2+}$ and $\mathrm{Ni}^{2+}$ were not competing for copper adsorption. The selectivity of PCEGC towards copper was confirmed for $\mathrm{R}=50$ with cobalt by UV-visible analyses (Cf. Figure 1). The spectra of PCEGC/Cu and - 19 - 
PCEGC/Cu/Co were equivalent regarding the wavelength absorption maximum and the absorbance. These assays were not possible with nickel because of the absorbance recovery with copper. In addition to these results, no desorption of copper occurred in favor of nickel $(0<\mathrm{R}<10)$ or cobalt complexation $(0<\mathrm{R}<50)$. This observation agreed with previous results about the selective complexation of copper by glycine groups [50].

\subsection{Sorption/Desorption cycles}

The reusability of PCEGC was explored by $\mathrm{pH}$ adjustment at 2 and 4.5 respectively for desorption and adsorption. Figure 6 confirms that the efficiency of copper adsorption was maintained over 5 cycles of PCEGC reuse $(91 \pm 4 \%)$. The selectivity toward copper in the presence of $\mathrm{Ni}$ (II) or $\mathrm{Co}$ (II) was also maintained in the same conditions (94 $\pm 3 \%$ and $96 \pm$ $3 \%$ respectively).

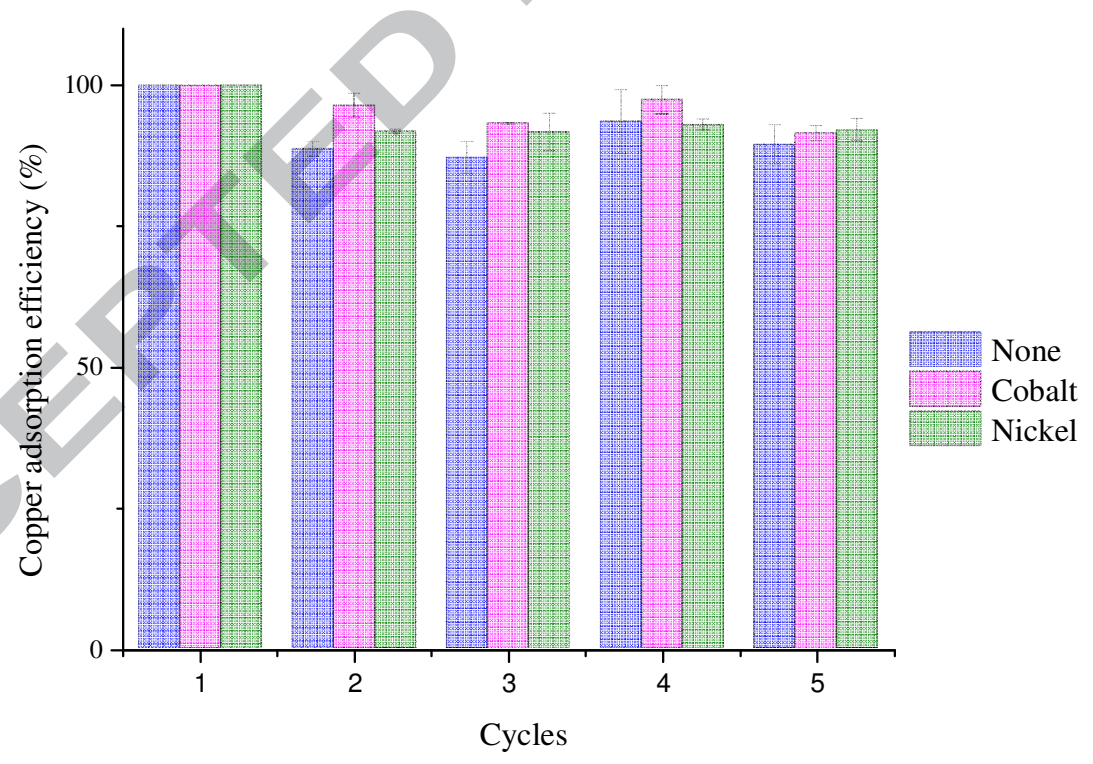

Figure 6. Copper adsorption efficiency over 5 cycles of sorption-desorption processes in the absence and in the presence of cobalt or nickel. 


\section{Conclusions}

Based on the functionalization of polycarboxyethyl-3-aminocrotonate, novel $\mathrm{pH}$ sensitive polycarboxybetaines were successfully prepared with the goal of achieving great complexing properties with copper. The maximal adsorption capacities recorded were shown to be $\mathrm{pH}$ dependent, reaching a value of $264 \pm 11 \mathrm{mg}$ of copper per $\mathrm{g}$ of polymer at $\mathrm{pH}=6$. The present study also revealed the highly selective properties of PCEGC toward copper in the presence of cobalt, nickel or zinc. This study will be continued to determine the coordinative chemistry of the PCEGC/Cu complexes. The relevance of using PCEGC in environmental applications (such as metal recovery from wastes/wastewaters or environmental sensors) was demonstrated. Using a sustainable strategy based on its $\mathrm{pH}$-sensitive properties, PCEGC reusability and the preservation of the copper adsorption efficiency and selectivity were also confirmed. The use of such materials for environmental applications is greatly encouraged. Further studies will be performed on copper recovery using PCEGC to design a full physicochemical process.

\section{References}

[1] M.A. Reuter, C. Hudson, A. Van Schaik, K. Heiskanen, C. Meskers, C. Hagelüken, Metal Recycling: Opportunities, Limits, Infrastructure; A Report of the Working Group on the Global Metal Flows to the International Resource Panel, 2013, pp. 316.

[2] S.A. Ali, O.C.S. Al Hamouz, N.M. Hassan, Novel cross-linked polymers having pHresponsive amino acid residues for the removal of $\mathrm{Cu} 2+$ from aqueous solution at low concentrations, J. Hazard. Mater. 248-249 (2013) 47-58.

[3] M. Ahmaruzzaman, Industrial wastes as low-cost potential adsorbents for the treatment of wastewater laden with heavy metals, Adv. Colloid Interface Sci. 166 (2011) 36-59. 
[4] J.F. Blais, Z. Djedidi, R.B. Cheikh, R.D. Tyagi, G. Mercier, Metals Precipitation from Effluents: Review, Practice Periodical of Hazardous, Toxic, and Radioactive Waste Management 12 (2008) 135-149.

[5] S.B. Chen, Y.B. Ma, L. Chen, K. Xian, Adsorption of aqueous $\mathrm{Cd} 2+, \mathrm{Pb} 2+, \mathrm{Cu} 2+$ ions by nano-hydroxyapatite: Single- and multi-metal competitive adsorption study, Geochem. J. 44 (2010) 233-239.

[6] H. Aydin, Y. Bulut, C. Yerlikaya, Removal of copper (II) from aqueous solution by adsorption onto low-cost adsorbents, J. Environ. Manage. 87 (2008) 37-45.

[7] T.C. Hsu, Experimental assessment of adsorption of $\mathrm{Cu} 2+$ and $\mathrm{Ni} 2+$ from aqueous solution by oyster shell powder, J. Hazard. Mater. 171 (2009) 995-1000.

[8] G.Z. Kyzas, M. Kostoglou, N.K. Lazaridis, Copper and chromium(VI) removal by chitosan derivatives—Equilibrium and kinetic studies, Chem. Eng. J. 152 (2009) 440-448.

[9] S.K. Papageorgiou, F.K. Katsaros, E.P. Kouvelos, N.K. Kanellopoulos, Prediction of binary adsorption isotherms of $\mathrm{Cu}(2+), \mathrm{Cd}(2+)$ and $\mathrm{Pb}(2+)$ on calcium alginate beads from single adsorption data, J. Hazard. Mater. 162 (2009) 1347-1354.

[10] M. Muratalin, P.F. Luckham, Preparation and characterization of microgels sensitive toward copper II ions, J. Colloid Interface Sci. 396 (2013) 1-8.

[11] S. Kudaibergenov, W. Jaeger, A. Laschewsky, Polymeric Betaines: Synthesis, Characterization, and Application, Adv. Polym. Sci. 201 (2006) 157-224.

[12] S. Kudaibergenov, Z. Adilov, D. Berillo, G. Tatykhanova, Z. Sadakbaeva, K. Abdullin, I. Galaev, Novel macroporous amphoteric gels: Preparation and characterization, Express Polym. Lett. 6 (2012) 346-353.

[13] J.-G. Noh, Y.-J. Sung, K.E. Geckeler, S.E. Kudaibergenov, Synthesis, characterization, and stimuli-sensitive properties of novel polycarbobetaines, Polymer 46 (2005) 2183-2190.

[14] N. Tarannum, M. Singh, Advances in Synthesis and Applications of Sulfo and Carbo Analogues of Polybetaines: A Review, Rev. Adv. Sci. Eng. 2 (2013) 90-111. 
[15] K.E. Geckeler, K. Volchek, Removal of Hazardous Substances from Water Using Ultrafiltration in Conjunction with Soluble Polymers, Environ. Sci. Technol. 30 (1996) 725 734.

[16] R. Molinari, P. Argurio, T. Poerio, G. Gullone, Selective separation of copper(II) and nickel(II) from aqueous systems by polymer assisted ultrafiltration, Desalination 200 (2006) 728-730.

[17] B.L. Rivas, E.D. Pereira, M. Palencia, J. Sánchez, Water-soluble functional polymers in conjunction with membranes to remove pollutant ions from aqueous solutions, Prog. Polym. Sci. 36 (2011) 294-322.

[18] I. Moreno-Villoslada, B.L. Rivas, Competition of Divalent Metal Ions with Monovalent Metal Ions on the Adsorption on Water-Soluble Polymers, J. Phys. Chem. B 106 (2002) 97089711.

[19] X.S. Wang, Y. Qin, Equilibrium sorption isotherms for of $\mathrm{Cu} 2+$ on rice bran, Process Biochem. 40 (2005) 677-680.

[20] K.Y. Foo, B.H. Hameed, Insights into the modeling of adsorption isotherm systems, Chem. Eng. J. 156 (2010) 2-10.

[21] K.K.H. Choy, J.F. Porter, G. McKay, Langmuir Isotherm Models Applied to the Multicomponent Sorption of Acid Dyes from Effluent onto Activated Carbon, J. Chem. Eng. Data 45 (2000) 575-584.

[22] I. Langmuir, The adsorption of gases on plane surfaces of glass, mica and platinium, J. Am. Chem. Soc. 40 (1918) 1361-1403.

[23] Y.S. Ho, J.F. Porter, G. McKay, Equilibrium Isotherm Studies for the Sorption of Divalent Metal Ions onto Peat: Copper, Nickel and Lead Single Component Systems, Water, Air, Soil Pollut. 141 (2002) 1-33. 
[24] K.R. Hall, L.C. Eagleton, A. Acrivos, T. Vermeulen, Pore- and Solid-Diffusion Kinetics in Fixed-Bed Adsorption under Constant-Pattern Conditions, Ind. Eng. Chem. Fundam. 5 (1966) 212-223.

[25] M. Hadi, M.R. Samarghandi, G. McKay, Equilibrium two-parameter isotherms of acid dyes sorption by activated carbons: Study of residual errors, Chem. Eng. J. 160 (2010) 408416.

[26] O. Hamdaoui, E. Naffrechoux, Modeling of adsorption isotherms of phenol and chlorophenols onto granular activated carbon: Part I. Two-parameter models and equations allowing determination of thermodynamic parameters, J. Hazard. Mater. 147 (2007) 381-394.

[27] J.P. Hobson, Physical adsorption isotherms extending from ultrahigh vacuum to vapor pressure, J. Phys. Chem. 73 (1969) 2720-2727.

[28] G.J. Copello, L.E. Diaz, V. Campo Dall' Orto, Adsorption of Cd(II) and Pb(II) onto a one step-synthesized polyampholyte: kinetics and equilibrium studies, J. Hazard. Mater. 217-218 (2012) 374-381.

[29] C. Nguyen, D.D. Do, The Dubinin-Radushkevich equation and the underlying microscopic adsorption description, Carbon 39 (2001) 1327-1336.

[30] M.M. Dubinin, The Potential Theory of Adsorption of Gases and Vapors for Adsorbents with Energetically Nonuniform Surfaces, Chem. Rev. 60 (1960) 235-241.

[31] Y. Kim, C. Kim, I. Choi, S. Rengaraj, J. Yi, Arsenic Removal Using Mesoporous Alumina Prepared via a Templating Method, Environ. Sci. Technol. 38 (2004) 924-931.

[32] AFNOR, Qualité de l'eau - Protocole d'évaluation initiale des performances d'une méthode dans un laboratoire, in: AFNOR (Ed.) NF T90-210, 2009, pp. 43 pages.

[33] A.G. Didukh, R.B. Koizhaiganova, L.A. Bimendina, S.E. Kudaibergenov, Synthesis and characterization of novel hydrophobically modified polybetaines as pour point depressants, J. Appl. Polym. Sci. 92 (2004) 1042-1048. 
[34] Z. Dai, A. Wolfsberg, P. Reimus, H. Deng, E. Kwicklis, M. Ding, D. Ware, M. Ye, Identification of sorption processes and parameters for radionuclide transport in fractured rock, Journal of Hydrology 414-415 (2012) 220-230.

[35] A.G. Didukh, R.B. Koizhaiganova, G. Khamitzhanova, L.A. Bimendina, S.E. Kudaibergenov, Stimuli-sensitive behaviour of novel betaine-type polyampholytes, Polym. Int. 52 (2003) 883-891.

[36] S.E. Kudaibergenov, L.A. Bimendina, M.G. Yashkarova, Preparation and Characterization of Novel Polymeric Betaines Based on Aminocrotonates, J. Macromol. Sci., Pure Appl. Chem. 44 (2007) 899-912.

[37] L. Cartechini, C. Miliani, B.G. Brunetti, A. Sgamellotti, C. Altavilla, E. Ciliberto, F. D'Acapito, X-ray absorption investigations of copper resinate blackening in a XV century Italian painting, Appl. Phys. A 92 (2008) 243-250.

[38] A. Karaliota, O. Kretsi, C. Tzougraki, Synthesis and characterization of a binuclear coumarin-3-carboxylate copper(II) complex, J. Inorg. Biochem. 84 (2001) 33-37.

[39] K.P. Burnham, D.R. Anderson, K.P. Huyvaert, AIC model selection and multimodel inference in behavioral ecology: some background, observations, and comparisons, Behav Ecol Sociobiol 65 (2010) 23-35.

[40] N. Kannan, M.M. Sundaram, Kinetics and mechanism of removal of methylene blue by adsorption on various carbons - a comparative study, Dyes Pigments 51 (2001) 25-40.

[41] J. Kong, Q. Yue, S. Sun, B. Gao, Y. Kan, Q. Li, Y. Wang, Adsorption of Pb(II) from aqueous solution using keratin waste - hide waste: Equilibrium, kinetic and thermodynamic modeling studies, Chem. Eng. J. 241 (2014) 393-400.

[42] K.S. Low, C.K. Lee, A.C. Leo, Removal of metals from electroplating wastes using banana pith, Bioresour. Technol. 51 (1995) 227-231. 
[43] S.K. Papageorgiou, E.P. Kouvelos, F.K. Katsaros, Calcium alginate beads from Laminaria digitata for the removal of $\mathrm{Cu}+2$ and $\mathrm{Cd}+2$ from dilute aqueous metal solutions, Desalination 224 (2008) 293-306.

[44] F. Veglio, A. Esposito, A.P. Reverberi, Copper adsorption on calcium alginate beads: equilibrium pH-related models, Hydrometallurgy 65 (2002) 43-57.

[45] X. Guo, S. Zhang, X.Q. Shan, Adsorption of metal ions on lignin, J. Hazard. Mater. 151 (2008) 134-142.

[46] C. Morlay, M. Cromer, O. Vittori, The removal of copper (II) and nickel (II) from dilute aqueous solution by a synthetic flocculant: a polarographic study of the complexation with a high molecular weight poly(acrylic acid) for different pH values, Water Res. 34 (2000) 455 462.

[47] R. Molinari, P. Argurio, T. Poerio, Comparison of polyethylenimine, polyacrylic acid and poly(dimethylamine-co-epichlorohydrin-co-ethylenediamme) in $\mathrm{Cu} 2+$ removal from wastewaters by polymer-assisted ultrafiltration, Desalination 162 (2004) 217-228.

[48] F. An, B. Gao, X. Dai, M. Wang, X. Wang, Efficient removal of heavy metal ions from aqueous solution using salicylic acid type chelate adsorbent, J. Hazard. Mater. 192 (2011) 956-962.

[49] V. Manu, H.M. Mody, H.C. Bajaj, R.V. Jasra, Adsorption of Cu2+ on Amino Functionalized Silica Gel with Different Loading, Ind. Eng. Chem. Res. 48 (2009) 8954-8960. [50] E.A. Oraby, J.J. Eksteen, The selective leaching of copper from a gold-copper concentrate in glycine solutions, Hydrometallurgy 150 (2014) 14-19. 


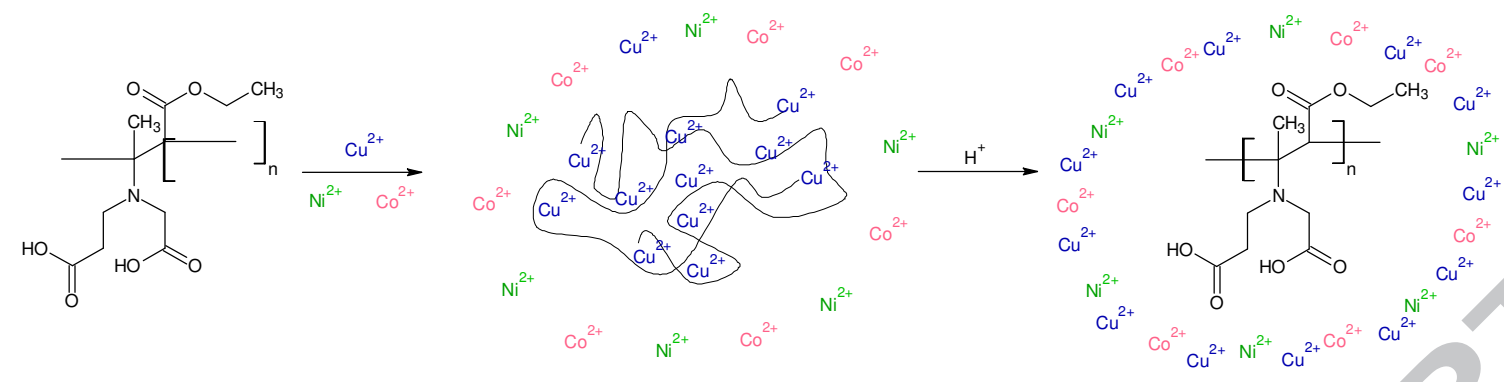

GRAPHICAL ABSTRACT 


\section{Highlights :}

- A new pH-sensitive polycarbobetaine was synthetized

- Adsorption isotherms were built and modeled

- High adsorption capacities were reached for copper at $\mathrm{pH}=5$ and $\mathrm{pH}=6$

- The selectivity toward copper was indicated in the presence of nickel and/or cobalt

- The efficiency of copper adsorption was maintained over 5 cycles of polycarbobetaine reuse 